\title{
Furrow irrigation and TOU electric rates
}

\begin{abstract}
Blaine R. Hanson $\square \quad$ Stuart Spoto
Time-of-use (TOU) electric rates offer growers an opportunity to reduce the cost of pumping irrigation water. Peak-hour electricity rates can run from two to four times the off-peak rates. Times designated as off- and on-peak vary depending on the utility's rate schedule.
\end{abstract}

Furrow irrigation systems present a unique challenge for growers attempting to operate pumps only during off-peak periods. The infiltration rate of a furrow-irrigated soil plays a major role in system performance. Thedesign and management of theirrigation system must accommodate that infiltration rate. Performance characteristics affected by the infiltration rate include advance time (the time required for water to reach the end of the field) and intake time (the time required to infiltrate the soil moisture deficit). The set time for furrow irrigation is equal to the advance time plus the intake time.

Where one or two irrigation sets are applied per day, advance times must be decreased to allow adequate irrigation in 18 hours instead of the normal 24. Irrigators can reduce advance times by increasing the furrow inflow rate, which means irrigating

- Kent Kaita a Todd W. Bruce

fewer furrows per set. However, more days will beneeded for each irrigation cycle. Also, a limited pump capacity may lead to deficit irrigation during periods of peak evapotranspiration.

When a set time extends over multiple days, irrigation must stop during on-peak hours topreventelectric ratepenalty charges. This can cause several problems. First, the water mustre-advanceacross the field when the interruption is over, resulting in less infiltration time compared to that of a continuous set. Second, the basic infiltration rate of the soil may decrease after the irrigation is interrupted, a phenomenon observed in surge irrigation, where irrigation water is cycled on and off. Thus, less water may infiltrate per unit of irrigation time than for a continuous operation.

The irrigator might be able to reduce these problems by selecting a time-of-use rate that provides fourcontinuousdaysmade up only of off-peak periods. Irrigation could continue 24 hours a day over those days. However, this means scheduling irrigations based on when those off-peak days happen to occur, and that might affect yield.

The bottom line is economics. If energy savings from off-peak operation exceed the costs of off-peak irrigation, the practice will increase profits. Costs may include revenue losses caused by deficit irrigation or by poor timing, as well as thecapital and labor needed convert to off-peak irrigation.
Three fields - labeled field 30 (52 acres), field $32 \mathrm{~N}$ ( 35 acres), and field $32 \mathrm{~S}$ ( 35 acres) - were selected for demonstrating off-peak irrigation. Tomatoes were grown in each field. The soil type was a clay loam. Furrow spacing was 60 inches. Durations of irrigations ranged from one to four days. Pump capacity was not a limiting factor. Pumping plant efficiencies were $66 \%$ (field 30 ) and $54 \%$ (field 32). The TOU electric rate designation was AG-4B.

Data collected included hours of pump operation and pump capacity for each field and each irrigation. Water advance and furrowinflow-outflow rates were measured in six furrows during selected irrigations. Inflow-outflow measurements made on a block of furrows were used to estimate cumulative intake. Yields for each field were compared to those for an adjacent field (field 33) irrigated continuously during each irrigation.

\section{Results and discussion}

Figure 1 shows outflow rates with time for 46 furrows in field 30 for the May 1-5 irrigation. Irrigations started at $6: 00 \mathrm{pm}$ and stopped at 12:00 noon the following day. Water was applied for 4 days. The block inflow ratewas about 258 gallons per minute (gpm), about $10 \mathrm{gpm}$ per furrow. For the first cycle, the maximum outflow rate was nearly $45 \mathrm{gpm}$. Thereafter, that rate ranged from 90 to $95 \mathrm{gpm}$.

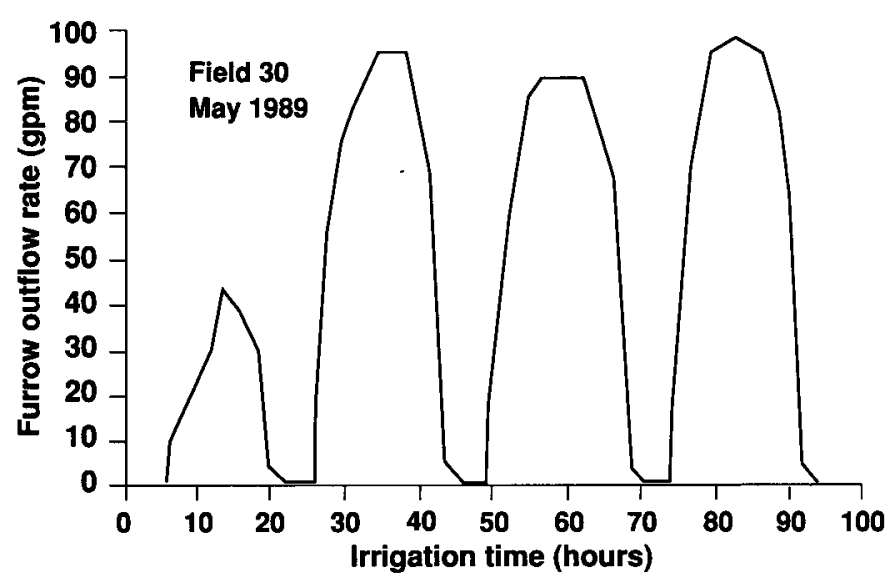

Fig. 1. Outflow rates for Field 30, irrigated in May, 1989. Each day's irrigation began at 6:00 pm and ended at noon of the following day.

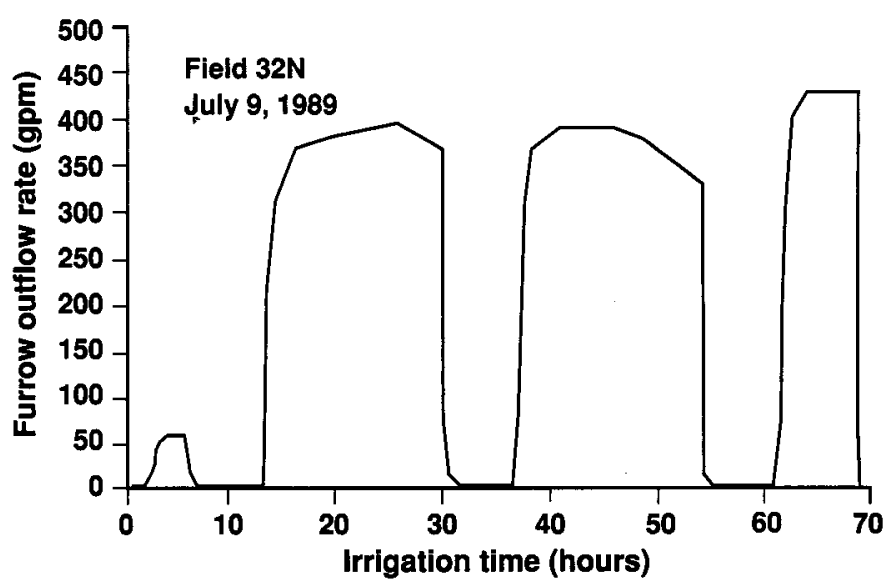

Fig. 2. Outflow rates for Field 32N, July, 1989. The first irrigation ran from 7:40 am to noon; the next two began at $6: 00 \mathrm{pm}$ and ended at noon of the following day; and the last ran from 6:00 pm to 2:00 am. 
The increase in the maximum outflow rates of the first and later cycles reflects a reduction in the basic intake rate. The basic rate was $0.49 \mathrm{gpm} / 100$ feet of furrow length for the first cycle, but decreased to about 0.30 $\mathrm{gpm} / 100$ feet for the remaining three cycles. The advance times to the end of the field (about 982 feet) ranged from 4.1 to 16.5 hours for the first cycle. Advance times were about 2 hours for all furrows for the second cycle. Similar times probably occurred for the third and fourth cycles, based on outflow data.

Cumulative inflow, outflow, and intake are listed in table 1. Each cycle applied about 2 inches of water. Surface runoff was 0.2 inches for the first cycle, and 0.6 inches for the remaining cycles. The amount of runoff was about $25 \%$ of the cumulative inflow. Approximately 1.8 inches infiltrated during the first cycle, and 1.4 inches during each remaining cycle. Cumulative intake was about 6 inches for the irrigation.

Table 2 shows cumulative amounts for the July 19-20 irrigation of field $32 S$. The irrigation time for each cycle was from 6:00 $\mathrm{pm}$ to 12:00 noon the following day. About 2.5 inches infiltrated during the first cycle, and about 1.6 inches during the second. The basic intake rate decreased from $0.44 \mathrm{gpm} /$ 100 feet to $0.19 \mathrm{gpm} / 100$ feet from the first to the second cycle. Water advance of the first cycle ranged from 7 to 9 hours, but was about 1 hour for the second.

Tabie 1. Cumulative amounts of applied water, surface runoff, and intake for Field 30 .

\begin{tabular}{|c|c|c|c|}
\hline Cycle & Inflow & Surface runoff & Intake \\
\hline & & inches... & \\
\hline 1 & 2.0 & 0.2 & 1.8 \\
\hline 2 & 2.0 & 0.6 & 1.4 \\
\hline 3 & 2.0 & 0.6 & 1.4 \\
\hline 4 & 2.0 & 0.6 & 1.4 \\
\hline Total & 8.0 & 2.0 & 6.0 \\
\hline
\end{tabular}

Table 2. Cumulative inflow, surface runoff, and intake for Field 32S, July 19-21, 1989

\begin{tabular}{lccc}
\hline Cycle & Inflow & Surface runoff & Intake \\
\hline & $\ldots \ldots \ldots \ldots \ldots \ldots \ldots . .$. & inches &..$\ldots \ldots \ldots \ldots \ldots \ldots \ldots \ldots \ldots \ldots \ldots \ldots$ \\
1 & 3.2 & 0.7 & 2.5 \\
2 & 3.2 & 1.6 & 1.6 \\
Total & 6.4 & 2.3 & 4.1 \\
\hline
\end{tabular}

Table 3. Cumulative inflow, surface runoff, and intake for Field 32N, June 6-9, 1989

\begin{tabular}{|c|c|c|c|}
\hline Cycle & Inflow & Surface runoff & Intake \\
\hline & & inches. & \\
\hline 1 & 0.6 & 0.02 & 0.58 \\
\hline 2 & 2.5 & 0.8 & 1.7 \\
\hline 3 & 2.5 & 1.0 & 1.5 \\
\hline 4 & 1.1 & 0.5 & 0.6 \\
\hline Total & 6.7 & 2.3 & 4.4 \\
\hline
\end{tabular}

Table 4. Amount of applied water

\begin{tabular}{|c|c|c|c|}
\hline Field & Pump capacity & Irrigation time & $\begin{array}{c}\text { Applied } \\
\text { water }\end{array}$ \\
\hline & $g p m$ & hours & inches \\
\hline 30 & 1,100 & 587 & 35 \\
\hline $32 \mathrm{~N}$ & 1,100 & 453 & 31 \\
\hline $32 S$ & 1,100 & 382 & 27 \\
\hline 33 & 1,500 & 685 & 45 \\
\hline
\end{tabular}

Figure 2 is a runoff hydrograph for an irrigation of field $32 \mathrm{~N}$. Thisirrigation started about 7:40 am and provided 4.3 hours of irrigation time for the first cycle. Later cycles started at 6:00 pm and lasted 18 hours for the second and third cycles and 8 hours for the lastcycle. The hydrographshowslittle runoff during the first cycle, and much more during the remaining cycles. Table 3 shows that about 0.6 inches infiltrated during the first cycle, whereas 1.5 to 1.7 inches infiltrated during the second and third cycles (the opposite of the behavior shown by the data in tables 1 and 2). These results show that starting theirrigation in the morning limited the amount of intake during the cycle with thehighestsoil intake rate. Irrigations should start at 6:00 pm to provide the maximum intakeopportunity timeat the highestintake rates.

Total applied water ranged from 27 to 45 inches for all monitored irrigations (table 4). The largeapplication for field 33 is caused by the small run lengths, the result of splitting the field to help compensate for variations in soil and slope. Measured amounts of surface runoff ranged from 15 to $36 \%$ of the applied water (table5). The smaller amount of runoff may reflect the intake rate of a recently cultivated field. Evapotranspiration (ET)-estimates range from 26 to 28 inches (based on historicalET).Tomato yields were 35.3 tons / acre (field 30), 33.2 tons/acre (field 33), 28.7

Table 5. Surface runoff as a percentage of amount of applied water

\begin{tabular}{llc}
\hline Field & Date & Percent \\
\hline 30 & May 1 & 25 \\
$32 \mathrm{~S}$ & July 6 & 15 \\
$32 \mathrm{~S}$ & August 11 & 18 \\
$32 \mathrm{~S}$ & July 19 & 36 \\
$32 \mathrm{~N}$ & June 6 & 35 \\
$32 \mathrm{~N}$ & July 21 & 32 \\
\hline
\end{tabular}

Table 6. Annual energy costs of the various TOU rate schedules

\begin{tabular}{lrr}
\hline TOU rate & $\begin{array}{c}18 \text { hours } \\
\text { per day }\end{array}$ & $\begin{array}{c}\text { 24 hours } \\
\text { per day }\end{array}$ \\
\hline Field 30 & & \\
AG-1B & $\$ 2,650$ & $\$ 2,650$ \\
AG-4B & 1,768 & 2,518 \\
Field 32 & & \\
AG-1B & 4,277 & 4,277 \\
AG-4B & 2,683 & 3,952 \\
Field 33 & & \\
AG-1B & 5,348 & 5,348 \\
AG-4B & 3,326 & 5,136 \\
\hline
\end{tabular}

Table 7. Economics of TOU irrigation

\begin{tabular}{lrrr}
\hline & $\begin{array}{c}\text { Field 30 } \\
\text { (plastic) }\end{array}$ & $\begin{array}{c}\text { Field } 32 \\
\text { (aluminum) }\end{array}$ & $\begin{array}{c}\text { Field } 32 \\
\text { (plastic) }\end{array}$ \\
\hline $\begin{array}{c}\text { Annual benefit } \\
\text { Energy savings }\end{array}$ & $\$ 750$ & $\$ 1,269$ & $\$ 1,269$ \\
Labor savings & 572 & 770 & 770 \\
$\begin{array}{c}\text { Annual cost } \\
\text { 1-year life }\end{array}$ & 1,148 & 6,700 & \\
2-year life & 629 & & 1,194 \\
Annual return & & 648 \\
1-year life & 174 & & 4,661 \\
2-year life & 693 & & 845 \\
\hline
\end{tabular}

tons/acre (field 32N), and 25.9 tons/acre (field 32S). Some of the differences may be attributed to different water applications, but variety differences may also be a factor. Note that the field with the greatest water application did not have the greatest yield.

\section{Economics}

Estimated annual energy costs for each field are shown in table 6 for each TOU rate. Costs are for an off-peak (18-hour-per-day) operation and a 24-hour-per-day operation. For each field, the flat rate (AG-1B) was the mostexpensive. The AG-4B TOU ratewould result in lower energy costs, even if the pump were operated 24 hours per day. Energy rates for the AG-4B rate range from $\$ 0.077 / \mathrm{kwhr}$ (off-peak operation) to $\$ 0.11 /$ $\mathrm{kwhr}$ (24-hours operation) for field 30, and $\$ 0.070 / \mathrm{kwhr}$ to $\$ 0.103 / \mathrm{kwhr}$ for field 32 . Actual energy usages were 22,745 kwhr for field $30,38,378 \mathrm{kwhr}$ for field 32 , and 47,200 $\mathrm{kwhr}$ for field 33 .

The costs of an off-peakoperation include the capital cost of providing flexible plastic gated pipe for field 30 and the rental cost of providing aluminum gated pipe for field 32 . A capital cost for flexible pipe was also estimated for field 32 . The flexible pipe cost \$253.13 for a 670-foot roll of 16 -inch diameter pipe. Gates cost $\$ 0.70$ each (520 gates for field 30 ). Renting the aluminum pipe cost $\$ 6,700$. Labor was estimated by the grower to be about $\$ 11 /$ acre less under the TOU operation than under normal conditions.

The estimated savings in energy costs realized by operating off-peak were $\$ 750$ and $\$ 1,269$ for fields 30 and 32 , respectively. Labor cost savings were $\$ 572$ and $\$ 770$ for the two fields, the result of using gated pipe instead of the normally used siphons. The economic analysis (table 7) revealed that field 30 would show a profit of $\$ 174$, assuming an economic life of 1 year for the flexible pipe ( 5 years for the gates). For a 2year economic life, the net return would be $\$ 693$. Aluminum pipe was unprofitable for field 32, realizing a net loss of $\$ 4,661$. If the flexible pipe were used, the net return would be $\$ 845$ (1-year life) or $\$ 1,391$ (2-year life).

\section{Other considerations}

This study involved multiple-day sets for which pump capacity was not a limiting factor (no deficit irrigation occurred during periods of maximum ET). However, where set times of 24 hours are common, off-peak irrigation requires that theset time bereduced to 18 hours or less. This is accomplished by decreasing the advance time (the time the water takes to flow to the end of the field) by using a larger furrow inflow rate. Furrow inflow rates should be increased by 35 to $40 \%$ to achieve the reduction needed for TOU irrigation.

If pump capacity is not a limiting factor, the furrow inflow rate can be increased by reducing the number of furrows irrigated 
per set. This approach will require more days per irrigation cycle, and thus higher labor costs. If the existing pump capacity is limiting such that days per irrigation cycle cannot be increased, TOU operation will require a new, higher-capacity pump and motor. If the annualized capital cost of the replacement pumping plant does not exceed the savings from off-peak operation, a profit will be realized from this change.

An economic analysis was made for a 156-acre cotton field where furrow inflow rates were increased by about $17 \%$ in order to reduce the set time to 18 hours. This percentage increase was based on data collected on this field. Instituting off-peak irrigation required replacement of both pump and motor, at a capital cost of $\$ 16,000$. The analysis showed an annual savingsinenergy costs of \$23/acre, an annualized capitol cost of $\$ 9 /$ acre, and an annual return of $\$ 14$ / acre. For these conditions, modifying the pumping plant for off-peak operation is profitable. Some other analyses under different conditions revealed similar results.

\section{Conclusions}

Profitability can be increased by operating off-peak under a time-of-use electric rate. However, required capital investments must be minimal to insure profitable TOU operation for the pump horsepower and the operating time for these fields.

Where the irrigation is stopped during the set to avoid peak period charges, the irrigation should start at 6:00 pm to provide a maximum intake opportunity time under relatively higher intake rates. Results of these evaluations show that steady-state intake rates decrease by about 39 to $57 \%$ after the first irrigation cycle.

Growers operating their pumps 24 hours per day will increase the profitability of their operations by changing from the flat rate to a time-of-use rate. This conversion would save $\$ 132$ for field $30, \$ 325$ for field 32 , and $\$ 212$ for field 33 at no cost. An economic analysis showed that conversion to off-peak irrigation increased profitability, even though the change required installation of a higher-capacity pump.

Pumps should be maintained at peak efficiency to insure maximum capacity. This could minimize any yield losses where pump capacity is limiting.

Blaine $R$. Hanson is Irrigation and Drainage Specialist and Kent Kaita is Staff Research Associate, Department of Land, Air, and Water Resources, University of California, Davis; and Stuart Spoto is Agricultural Services Coordinator and Todd W. Bruce is Agricultural Services Representative, Pacific Gas and Electric Company, Davis and Dixon, respectively.

The authors gratefully acknowledge the assistance of Mike Noggle, Marketing Department Program Manager, Pacific Gas and Electric Company.

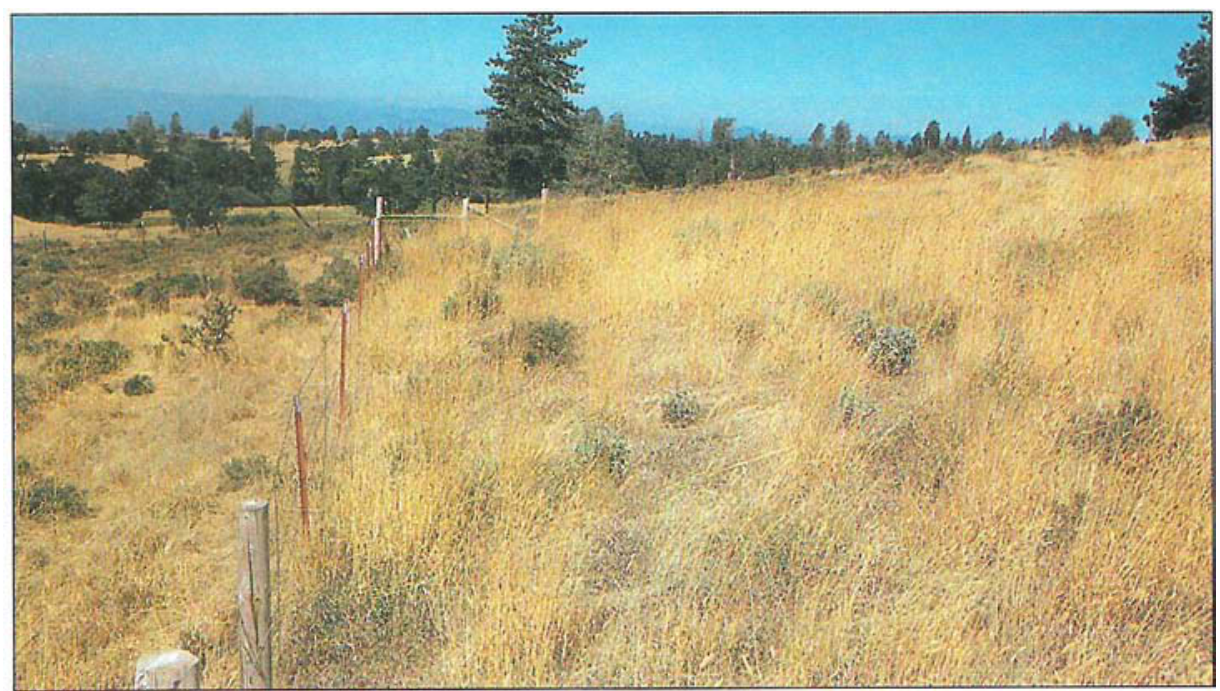

Vegetation patterns differ dramatically on two sides of the cattle exclosure fence.

\title{
Grazing helps maintain brush growth on cleared land
}

\author{
Walter H. Johnson $\square \quad$ E. Lee Fitzhugh
}

\section{A 20-year photographic record shows that grazing by deer and cattle can maintain forage after brush clearing.}

For decades, California ranchers have reduced brush cover to increase livestock forage. Brush control has also reduced fire hazard and soil erosion, increased water yield, and often improved wildlife habitat. Browsing by cattle and deer slowed the regrowth of brush and postponed the need for follow-up mechanical, chemical, or burning treatments. A20-year photographic record and transect data show how browsing by deer only and by cattle and deer can maintain forage appropriate for deer and livestock.

\section{Demonstration area}

The demonstration site is on a ranch in the Sierra Nevada foothills, 22 airline miles east of Redding and 2,200 feet above sea level. Summers are warm and dry with temperatures up to or above $100^{\circ} \mathrm{F}$; winter minimums may go below $20^{\circ} \mathrm{F}$. Annual precipitation averages 50 to 55 inches. Snow falls five or six times each winter. The soil is a fineloamy, mixed, mesic pachic argixeroll identified as Supan gravelly loam in the 1974 USDA Soil Survey of Shasta County.

The site is on a small hill in a large cleared area just below the edge of an extensive ponderosa pine forest. Irrigated swales nearby may increase cattle use of the study area. Surrounding vegetation includes blue oak, digger pine, manzanita, Ceanothus species, annual grasses, forbs, legumes, and occasional patches of live oak, black oak, and ponderosa pine. Cattle usually graze from March into November. Deer migrate through the area from March to April and October to November.

In 1960, bulldozers cleared brush and some trees from the area. After clearing, the area was seeded with rose clover, subterranean clover, and harding grass. Livestock and deer used the site for 9 years until the California Department of Fish and Game helped build two contiguous exclosures in 1969 on an area of about 0.9 acres. One exclosure allowed access for deer, but not for cattle. The other, made of woven wire 8 feet high, excluded both deer and cattle. In September 1976, 300 pounds per acre of single superphosphate fertilizer was applied by airplane.

\section{Exclosure monitoring}

On September 12, 1969, the same year the exclosures were built, the plant composition within each exclosure was recorded on four step-point transects. Each transect had 25 points three steps apart. "Hits" were recorded on stems and foliage of live perennials and live or dead annuals from the current year. We omitted measuring the transects in intervening years so we would not trample plants during sampling. We took pictures during midsummer from 1970 through 1989 at 11 photo stations.

We remeasured the transects on May 2, 1985 , but it was impossible to walk in a 